\title{
平面宇宙ロボットの滑らかな時不変フィードバック制御
}

\author{
ランジャン・ムカジー*1 掃 部 雅 幸*2 泉 田啓*3
}

\section{Control of Planar Space Robots Using Smooth and Time-Invariant Feedback}

\author{
Ranjan Mukherjee ${ }^{* 1}$, Masayuki Kamon*2 and Kei Senda*3
}

\begin{abstract}
In this paper we address the problem of reconfiguration of a freely floating planar space robot. Such a system is nonholonomic in nature due to the conservation of its angular momentum. This paper presents a smooth and time-invariant feedback control strategy that asymptotically converges the system states from practically any configuration to the desired configuration. The controller does not render the desired configuration asymptotically stable in the sense of Lyapunov but suffers from no convergence problem. The control strategy, though time-invariant, uses a nonlinear oscillator and extends the concept of geometric phase to control. In certain situations the controller has a slow rate of convergence but this problem can be easily rectified by simple modifications, as suggested in this paper. A stability analysis of the closed loop system using the original controller is only presented but results of numerical simulation indicate that both the modified controllers as well as the original controller can converge the system states to their desired values satisfactorily.
\end{abstract}

Key Words: Planar Space Robot, Smooth and Time-invariant Feedback Control, Nonlinear Oscillator

\section{1. 緒論}

軌道上で搭乗員の船外活動を代行する宇宙ロボットを実現す るためには，関節運動で多体系の向きと姿勢を変える制御方 策が望まれる。この内部運動中には外力と外トルクが作用しな いので, 系の角運動量が保存され, 系の運動に非ホロノミック 拘束を課す [1]. 非ホロノミック系は一般に可制御ではあるが, 滑らかな時不変状態フィードバック系では安定化できない[2].

非ホロノミック系の安定化制御器の研究を要約するが, 網羅 的ではないので, 文献[3]も参照されたい. 経路追従やある多 様体への安定化といった制御問題とは異なり, 平衡状態へ安定 化させるという非常に一般的な制御目的に，標準的な非線形制 御法は使えない。これは, Brockettのフィードバック安定化の 必要条件 [2] からの帰結であり, 閉ループ系の平衡状態を漸近 安定化する骬らかな時不变状態フィードバックが存在しないこ とを含意する。この必要条件を回避するために開発されてきた 安定化法は, 次のように分類できる：(i) 滑らかな時变安定化,

\footnotetext{
原稿受付 1997 年 6 月 30 日

*1ミシガン州立大学.学部

*2川崎重工業 (侏)

$* 3$ 大阪府立大学工学部

${ }^{* 1}$ College of Engineering, Michigan State University

${ }^{* 2}$ Kawasaki Heavy Industry, Co. Ltd.

${ }^{*}$ College of Engineering, Osaka Prefecture University

†姿勢」という言葉を「関節位置のみによって決まるマニピュレー夕の 形態」という意味に用い,「物体の向き」という意味には用いない。
}

（ii）滑らかでない時不変安定化,（iii）複合した安定化. 時変安 定化には[4]などがあるが, 遅い収束に悩まされるという特徵 がある [5]. 滑らかでない制御器 [6] [7] または複合制御器 [8]を 用いると, より早い収束が達成できる。複合制御器は, 区分的 な時間ごとに様々な低位の連続時間制御器を切り換える.

移動ロボットとリアクションホイールを 2 個搭載した衛星の 研究は多いが, 宇宙ロボットのフィードバック安定化を議論し ている論文はほとんどない。この分野の研究は初期より運動計 画に焦点を当ててきた [1] [9] [19]. 最近, 平面宇宙多体系の安 定化法が Kolmanovsky and McClamroch [20]により二つ提 案されたが, 滑らかでない時不変制御器はチャタリングに陥り, 滑らかな時変制御器は非指数的で遅い収束に悩まされた。また，

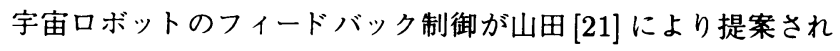
たが，近似的方法であり，安定性の議論は不十分である。

本論文では，平面宇宙ロボットに対して，ほとんど任意の初 期状態から平衡状態へ漸近安定化できる, 滑らかで時不変の フィードバック制衙法を示す.この制御器は, 平衡状態をリヤ プノフの意味で漸近安定化するものではないが, 実用上の問題 はない.また, 軌道の有界性を保証するので, 平衡点をリヤプ ノフの意味で安定化する. 非ホロノミック系に対する, 既存の 滑らかな時変制御法では線形振動子を用いるが [3], 本論文で は，その代わりにファン・デル・ポール振動子 $[22]$ の一種であ る非線形振動子を用いる. その結果, 滑らかで時不変のフィー ドバック制御が得られる。この制御器は, 幾何学的位相の概念 
を制御に拡張するものであり，非ホロノミック系の制御に本質 的に新しい方法をもたらす。

この論文の構成は，以下のとおりである．2 章では，系のモデ ルと数学的準備について述べる. 滑らかで時不変の制御方法を 3 章で示す. 閉ループ系の平衡状態への渐近収束は 4 章で立証 する，目標の関節位置がゼロホロノミー曲線に近いときに，収 束率が悪いという問題を克服するために，5 章では修正制御器 を二つ提案する．四つの異なった場合に対するシミュレーショ ンを 6 章で示すが, そのうちの二つは修正制御器によるもので ある。結論を 7 章で示す。

\section{2. 系のモデルと数学的準備}

\section{1 角運動悬保存}

台座のリンクと 2 回転関節を持つ 2 リンクマニピュレータか ら構成される平面宇宙ロボット（Fig. 1）を考える.

外力と外トルクが作用しないので，多体系の並進と回転の運 動量が保存される. 初期時刻において, 全系の並進と回転の運 動量がともに零と仮定する。この並進運動量の保存は，ロボッ トの質量中心が慣性的に不動であることを意味する。それゅえ， 系の一般化座標を, 台座リンクの方向 $\theta$, マニピュレータの関 節角 $\phi_{1}$ と $\phi_{2}$ からなるように選ぶことができる（Fig. 1).

この 3 リンク系の角運動量保存則は，次のように表せる.

$$
\dot{\theta}=h_{1}\left(\phi_{1}, \phi_{2}\right) \dot{\phi}_{1}+h_{2}\left(\phi_{1}, \phi_{2}\right) \dot{\phi}_{2}
$$

$h_{1}$ と $h_{2}$ は関節角の解析関数で, 各リンクの幾何学パラメータ

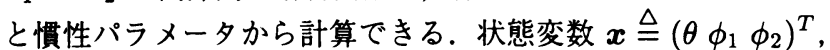
制御入力 $u_{1} \triangleq \dot{\phi}_{1}, u_{2} \triangleq \dot{\phi}_{2}$ に対し, 状態方程式は次式となる.

$$
\dot{\boldsymbol{x}}=\boldsymbol{h}_{1} u_{1}+\boldsymbol{h}_{2} u_{2}
$$

$$
h_{1} \triangleq\left(\begin{array}{lll}
h_{1} & 1 & 0
\end{array}\right)^{T}, \quad h_{2} \triangleq\left(\begin{array}{lll}
h_{2} & 0 & 1
\end{array}\right)^{T}
$$

2.2 一次 Lie 括弧樌運動とゼロホロノミー曲線 式（2）中のベクトル $h_{1}$ と $h_{2}$ の Lie 括弧積は

$$
\boldsymbol{h}_{3} \triangleq\left[\boldsymbol{h}_{1}, \boldsymbol{h}_{2}\right] \triangleq\left\{\frac{\partial \boldsymbol{h}_{2}}{\partial \boldsymbol{x}} \boldsymbol{h}_{1}-\frac{\partial \boldsymbol{h}_{1}}{\partial \boldsymbol{x}} \boldsymbol{h}_{2}\right\}
$$

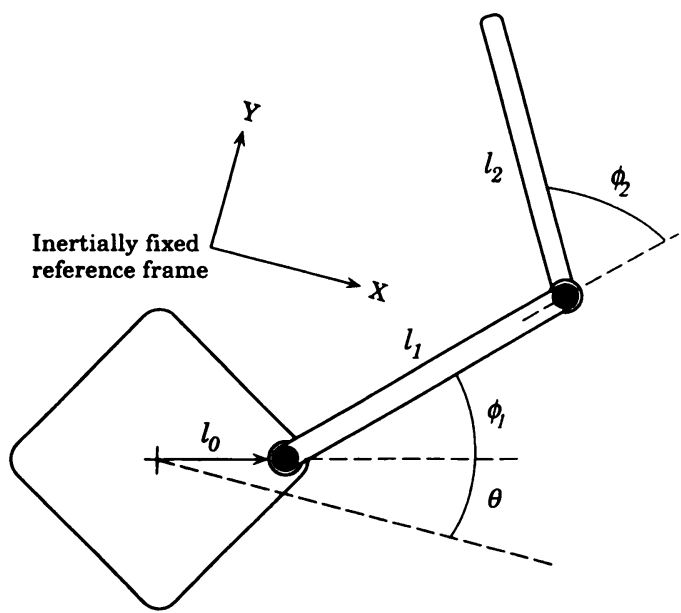

Fig. 1 A planar space robot with three links
ただし, $h_{3}=\left(h_{3} \quad 00\right)^{T}, h_{3} \triangleq\left(\partial h_{2} / \partial \phi_{1}-\partial h_{1} / \partial \phi_{2}\right)$ である. マニピュレータの姿勢空間における $h_{3}$ の図（Fig. 2) は， $h_{3}$

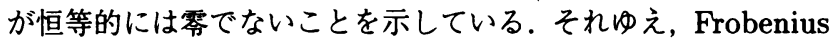
の定理 [22] より, 式 (1) の拘束は非ホロノミックであると演 繹できる。この非ホロノミックな性質は, 式 (1) を時間に関し て積分しても理解できる．積分すると

$$
\Delta \theta=\int_{\mathrm{P}}\left(h_{1} d \phi_{1}+h_{2} d \phi_{2}\right)
$$

となるが，P はマニピュレー夕の姿勢空間 $[17]$ として知られる $\phi_{1}-\phi_{2}$ 平面における経路である. 明らかに, 方向変数 $\theta$ の変 化は, $\phi_{1}$ と $\phi_{2}$ の両端値のみならず, 経路 $\mathrm{P}$ に依存している. もし, 経路が閉じていると, $\theta$ の変化は

$$
\Delta \theta=\oint_{\mathrm{C}}\left(h_{1} d \phi_{1}+h_{2} d \phi_{2}\right)= \pm \iint_{S} h_{3}\left(\phi_{1}, \phi_{2}\right) d \phi_{1} d \phi_{2} \quad(5)
$$

で与えられる。ここで，C は閉じた経路， $S$ は C で囲まれた 領域, 式 (5) 中の符号は閉じた経路 C の方向に依存し, 移動 方向が時計方向だと正, 反時計方向では負となる. $\phi_{1}-\phi_{2}$ 平面 上で, $h_{3}$ が恒等的に零ではないので, 独立変数 $\phi_{1}$ と $\phi_{2}$ の閉 ループ運動によって, 従属変数 $\theta$ が変化することは明らかで ある.

一次 Lie 括弧積 $h_{3}$ は， $\phi_{1}-\phi_{2}$ 平面の特定の点では零である. そのような特異点 [11] の軌跡はFig. 2 に示されている.この曲 線をゼロホロノミー（zero-holonomy）曲線と呼ぶ. 平面宇宙 ロボットの運動計画問題 [23] や制御問題を考える際, この曲線 を考慮することは重要である. 説明のために, 積分法の第一平 均値定理を用い, 式（5）を次のように書き換える。

$\Delta \theta= \pm \iint_{S} h_{3}\left(\phi_{1}, \phi_{2}\right) d \phi_{1} d \phi_{2}= \pm h_{3}\left(\phi_{1}^{*}, \phi_{2}^{*}\right) \iint_{S} d \phi_{1} d \phi_{2}$ ここで, $\phi_{1}^{*}, \phi_{2}^{*}$ は, 閉曲線 C のなかにある点である. 閉曲 線 $\mathrm{C}$ がゼロホロノミー曲線を横切る場合, $h_{3}\left(\phi_{1}^{*}, \phi_{2}^{*}\right)$ は零か もしれない，その場合， $\Delta \theta$ は零になるので，関節の閉ループ 運動によって，この宇宙ロボットの方向を変えることはできな い. また, $h_{3}\left(\phi_{1}^{*}, \phi_{2}^{*}\right)$ が小さい場合も方向転換は困難である.

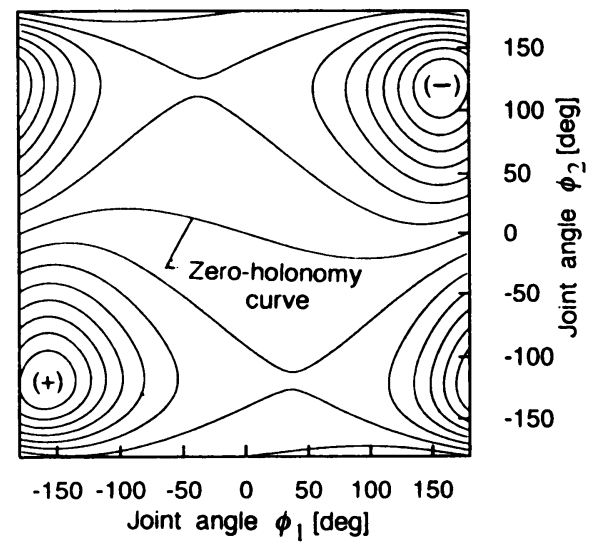

Fig. 2 Contour plot of $h_{3}$ in the $\phi_{1}-\phi_{2}$ space and the zeroholonomy curve 


\section{3. 滑らかな時不変フィードバック制御法}

\section{1 問題定義}

フィードバック漸近安定化問題は, 状態 $\boldsymbol{x}=\left(\theta \phi_{1} \phi_{2}\right)^{T}$ を 目標值 $x_{d}=\left(\theta_{d} \phi_{1 d} \phi_{2 d}\right)^{T}$ 一漸近安定化する制御入力 $u_{1}, u_{2}$ を設計する問題と定義される. 状態变数の誤差を

$$
\widehat{\theta} \triangleq\left(\theta-\theta_{d}\right), \quad \widehat{\phi}_{1} \triangleq\left(\phi_{1}-\phi_{1 d}\right), \widehat{\phi}_{2} \triangleq\left(\phi_{2}-\phi_{2 d}\right)
$$

と定義すると, フィードバック漸近安定化は， $t \rightarrow \infty$ のとき

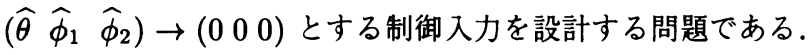

\section{2 極座標への変換}

関節变数の誤差を直交座標として取り扱い，それらを次のよ うに, $r$ と $\psi$ の極座標に変換する.

$$
\begin{aligned}
& \widehat{\phi}_{1} \triangleq\left(\phi_{1}-\phi_{1 d}\right)=r \cos \psi \\
& \widehat{\phi}_{2} \triangleq\left(\phi_{2}-\phi_{2 d}\right)=r \sin \psi
\end{aligned} \quad r \geq 0
$$

式 (6) で表される逆変換 $(r, \psi) \rightarrow\left(\widehat{\phi}_{1}, \widehat{\phi}_{2}\right)$ は至る所で定義さ れる. しかし, 順変換は, $r=0$ である $\left(\widehat{\phi}_{1}, \widehat{\phi}_{2}\right)=(0,0)$ では 定義されない．ほかのすべての点で，順変換を次のように定義 する。

$$
r=\sqrt{{\widehat{\phi_{1}}}^{2}+\widehat{\phi}_{2}^{2}}, \psi=\tan ^{-1}\left(\widehat{\phi}_{2} / \widehat{\phi}_{1}\right), r \neq 0
$$

式（6）とその微分を式（1）に代入すると, 角運動量保存則 の極座標表現を得るので，簡潔に標記すると次のようになる.

$$
\begin{aligned}
\dot{\theta} & =\eta_{1}(r, \psi) \dot{r}+\eta_{2}(r, \psi) \dot{\psi} \\
\eta_{1}(r, \psi) & =h_{1}(r, \psi) \cos \psi+h_{2}(r, \psi) \sin \psi \\
\eta_{2}(r, \psi) & =-h_{1}(r, \psi) r \sin \psi+h_{2}(r, \psi) r \cos \psi
\end{aligned}
$$

\section{3 動径不变向角：定義と解釈}

新しい変数, 動径不変向角 $\beta$ を次のように定義する.

$$
\beta=\widehat{\theta}-\int_{0}^{r}[d \theta]_{\psi: \text { const }}=\widehat{\theta}-\int_{0}^{r} \eta_{1}\left(r^{\prime}, \psi\right) d r^{\prime}
$$

ただし, 式 (10) の右辺第二項は, 関節変数を直線的に目標値 に移動させると生じる方向の変化である．関節変数が Fig. 3 の $\mathrm{A}$ から $\mathrm{B}$ へ至る開いた経路 $\mathrm{P}$ に沿って動くときの $\beta$ の変化は

$$
\begin{aligned}
\Delta \beta_{\mathrm{A} \rightarrow \mathrm{B}} & =\left(\beta_{\mathrm{B}}-\beta_{\mathrm{A}}\right) \\
& =\widehat{\theta}_{\mathrm{B}}-\int_{0}^{r_{2}} \eta_{1}\left(r^{\prime}, \psi_{2}\right) d r^{\prime}-\widehat{\theta}_{\mathrm{A}}+\int_{0}^{r_{1}} \eta_{1}\left(r^{\prime}, \psi_{1}\right) d r^{\prime} \\
& =\oint_{\mathrm{OABO}}\left(h_{1} d \phi_{1}+h_{2} d \phi_{2}\right)=\iint_{S} h_{3} d \phi_{1} d \phi_{2}
\end{aligned}
$$

ここで, $\mathrm{OABO}$ は経路 $\mathrm{P}$ の $\psi=\psi_{1}$ と $\psi=\psi_{2}$ の動径線との 交わりによってできる閉じた経路， $S$ は閉経路 OABOによっ て囲まれる領域である，明らかに，関節が通過する経路が開経 路であっても， $\beta$ の変化は面積分によって評価できる. それゆ え, $\beta$ は開経路 $\mathrm{AB}$ に関する幾何学的位相を表す. 定義より, $\beta$ は原点 $\left(\widehat{\phi}_{1}, \widehat{\phi}_{2}\right)=(0,0)$ を通る各動径方向の線に沿って一定 である。これが， $\beta$ を“動径不変向角”と呼ぶ理由である。

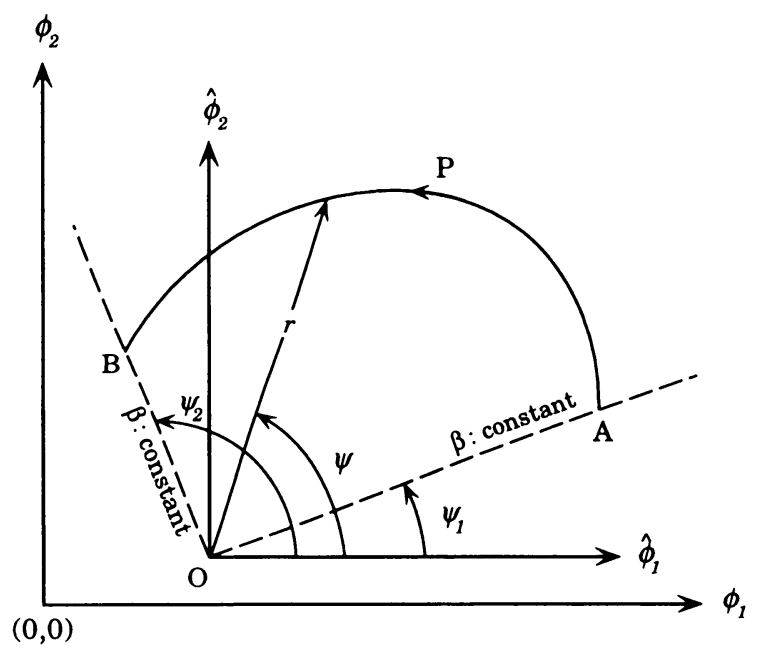

Fig. 3 Interpretation of radially isometric orientation

式（10）を微分することにより， $\dot{\beta}$ が次のように得られる.

$$
\begin{aligned}
\dot{\beta} & =\dot{\theta}-\frac{d}{d t} \int_{0}^{r} \eta_{1}\left(r^{\prime}, \psi\right) d r^{\prime} \\
& =\left(\eta_{2}-\int_{0}^{r} \frac{\partial \eta_{1}\left(r^{\prime}, \psi\right)}{\partial \psi} d r^{\prime}\right) \dot{\psi}
\end{aligned}
$$

$\eta_{3}$ と $\eta_{4}$ を

$$
\eta_{3}(r, \psi) \triangleq \frac{\partial \eta_{2}}{\partial r}-\frac{\partial \eta_{1}}{\partial \psi}, \eta_{4}(r, \psi) \triangleq \int_{0}^{r} \eta_{3}\left(r^{\prime}, \psi\right) d r^{\prime}
$$

と定義すると, 式 (11) は, 次のように書き換えられる.

$$
\dot{\beta}=\dot{\psi} \int_{0}^{r}\left(\frac{\partial \eta_{2}\left(r^{\prime}, \psi\right)}{\partial r^{\prime}}-\frac{\partial \eta_{1}\left(r^{\prime}, \psi\right)}{\partial \psi}\right) d r^{\prime}=\eta_{4} \dot{\psi}
$$

注 1： $\eta_{1}$ が複雑なため, 式（10）の右辺第二項の積分の閉じ た解が得られず， $\beta$ を計算する際には数値積分している. しか し, $\beta$ は $\theta, \phi_{1}, \phi_{2}$ のみに依存する静的な变数である.

\section{4 フィードバック制御法}

まず，式（6）と式（10）を用いて，等価なシステムを作る。

$$
\dot{\boldsymbol{y}}=\boldsymbol{g}_{1} v_{1}+\boldsymbol{g}_{2} v_{2}
$$

ここで, $\boldsymbol{y} \triangleq\left(\begin{array}{lll}\beta & r \psi\end{array}\right)^{T}, \boldsymbol{g}_{1} \triangleq\left(\begin{array}{lll}0 & 1 & 0\end{array}\right)^{T}, \boldsymbol{g}_{2} \triangleq\left(\begin{array}{lll}\eta_{4} & 0 & 1\end{array}\right)^{T}$ で あり， $v_{1} \triangleq \dot{r}, v_{2} \triangleq \dot{\psi}$ と定義される.フィードバック制御は, 式 (14) に対して $t \rightarrow \infty$ のときに $(\beta, r) \rightarrow(0,0)$ とする制御 変数 $v_{1}$ と $v_{2}$ を設計することである. 実際 $(\beta, r)=(0,0)$ の とき $\left(\widehat{\theta}, \widehat{\phi}_{1}, \widehat{\phi}_{2}\right)=(0,0,0)$ である. 滑らかで時不変のフィード バック制御 $v_{1}$ と $v_{2}$ を次のように提案する.

$$
\begin{aligned}
& v_{1}=\alpha r\left(\sigma^{2} \tanh \left[n_{1} \beta^{2}\right]-r^{2}\right) \\
& v_{2}=-\gamma \operatorname{sign}\left[h_{3}\left(\phi_{1 d}, \phi_{2 d}\right)\right] \tanh \left[n_{2} \beta\right]
\end{aligned}
$$

ただし， $\beta$ は式（10）より求める。また，次の仮定をおく．

$$
r(0) \neq 0, \quad h_{3}\left(\phi_{1 d}, \phi_{2 d}\right) \neq 0
$$


部雅幸泉田啓

制御器パラメー夕 $\alpha, \gamma, n_{1}, n_{2}$ は正の数, $\sigma$ は適切に選ばれ た正の数である． $\sigma$ の適切な選び方は， 4 章で述べる.

宇宙ロボットに対する実際の制御入力である式（2）の $u_{1}$, $u_{2}$ は, 式 (15) と式 (16) の制御変数 $v_{1}, v_{2}$ と式 (6) の時 間微分によって関係づけられる。 それゆえ, 制御入力は

$$
\begin{aligned}
& u_{1}=\cos \psi v_{1}-r \sin \psi v_{2} \\
& u_{2}=\sin \psi v_{1}+r \cos \psi v_{2}
\end{aligned}
$$

で与えられる. 式 (18) の制御は, 初期時に $r=0$ の点, また は, $\phi_{1}(0)=\phi_{1 d}$ かつ $\phi_{2}(0)=\phi_{2 d}$ の点から, 原点へ系の状態 を安定化することはできない. それゆえ, 閉ループ系の平衡点 の漸近安定性を要請しないことにする．この状況を除いては， 任意の系の状態から平衡状態に渐近的に収束できる。このこと は, 次の注と 6 章のシミュレーション結果で説明する.

注 $2 ： r(0)$ と $h_{3}\left(\phi_{1 d}, \phi_{2 d}\right)$ が厳密に零である領域は大きさ を持たないので, 式 (17) の二つの仮定は, 春用上の問題にな らない. 式 (15) と定義 $v_{1}=\dot{r}$ より, $\beta \neq 0$ のときに $r=0$ は不安定な平衡点である．第一の仮定は，この不安定な平衡点 に系の軌道がとどまらないことを保証する，第二の仮定は，目 標の関節位置が厳密にゼロホロノミー曲線の上に来ないために 必要である。これは, 式 $(16)$ の $v_{2}$ が常に零ではないことを 保証する。

注 3：式（18）の制御器は滑らかで至るところで定義される. $r=0$ では変数 $\psi$ は定義できなくなるが, $\cos \psi$ と $\sin \psi$ の 項は有界なままである。さらに，式（15）から分かるように， $r \rightarrow 0$ のときに制御変数は $v_{1} \rightarrow 0$ となる. それゆえ, $u_{1}$ と $u_{2}$ は至るところ定義され, $r \rightarrow 0$ の極限で消失する.

\section{4. 安定性解析}

この章では, 式 (18) の制御 $u_{1}, u_{2}$ が, 式 (2) の系の状態 $\left(\theta, \phi_{1}, \phi_{2}\right)$ を目標值に渐近的に収束させることを証明する。

㭪題 1 ： $r$ の軌道は, 大域的かつ一様に終局的有界である. 証明：次のスカラー関数を考虑する.

$$
V(r)=\frac{1}{2} r^{2}
$$

関数 $V$ は以下の条件を満たす：(a) $V \geq 0$, (b) $r \rightarrow \infty$ のと きに $V \rightarrow \infty,($ c) $V$ は $r$ に関して一回連続偏微分可能. 系の 軌道に沿った $V$ の微分は, 式（15）を用いると

$$
\dot{V}=r \dot{r}=-\alpha r^{2}\left(r^{2}-\sigma^{2} \tanh \left[n_{1} \beta^{2}\right]\right)
$$

となる.閉じた有界集合 $M=\left\{r \in R: r \leq \sigma \sqrt{\tanh \left[n_{1} \beta^{2}\right]}\right\}$ を定義し， $M_{\epsilon} \supset M$ を $M$ からの距離が正の微小量 $\epsilon$ よ り小さいすべての点の集合とし, $M_{\epsilon}^{C}$ を $M_{\epsilon}$ の補集合と する。すると, $V$ とその微分が次の条件を満たすことは容 易に分かる：(i) すべての $r_{1} \in M$ と $r_{2} \in M_{\epsilon}^{C}$ に対し て $V\left(r_{1}\right)<V\left(r_{2}\right)$, かつ（ii）すべての $r \in M_{\epsilon}^{C}$ に対して $\dot{V} \leq-\alpha \epsilon\left(\epsilon+2 \sigma \tanh \left[n_{1} \beta^{2}\right]\right)\left(\epsilon+\sigma \tanh \left[n_{1} \beta^{2}\right]\right)^{2}<0$. えに, $r$ の軌道が大域的かつ一様に終局的有界であることは文 献 [24]より結論づけられる.

注 4: $\quad r$ の一様な終局的有界性は, $r$ の軌道が有限時間 は $M_{\epsilon}$ のなかにとどまることを保証する，閉じた有界集合
$N=\{r \in R: r \leq \sigma\}$ を考え, $M$ に対する $M_{\epsilon}$ と同様に $N_{\epsilon}$ を定義すると， $N_{\epsilon} \supset M_{\epsilon}$ なので， $r$ の一様な終局的有界性は， $r$ の軌道が有限時間は $N_{\epsilon}$ のなかにとどまることも意味する。

補題 2: 式 (16) の制御入力 $v_{2}$ を用いると, 動径不変向角 $\beta(t)$ は，任意の有限時間において有界である.すなわち， $\beta(t)$ は有限発散時刻を持たない。

証明：式 (3) の $h_{3}$ は, 有界かつ $\phi_{1}$ と $\phi_{2}$ において周期的 である。これは, Fig. 2 の $h_{3}$ の図から明らかである. 補題 1 から, $r$ は大域的かつ一様に終局的有界であることが分かって いる. 式 (12) の $\eta_{3}$ と式 $(3)$ の $h_{3}$ の関係を計算すると

$$
\eta_{3}=r h_{3}
$$

となるので, $\eta_{3}$ は一様有界である.ゆえに, 式 (12) より, $\eta_{4}$ も一様有界である. 式 (13) と制御変数 $v_{2}=\dot{\psi}$ の定義より,

$$
\dot{\beta}=\eta_{4} \dot{\psi}=-\gamma \eta_{4} \operatorname{sign}\left[h_{3}\left(\phi_{1 d}, \phi_{2 d}\right)\right] \tanh \left[n_{2} \beta\right]
$$

を得る.上式の右辺が有界なので, 動径不変向角 $\beta(t)$ は, 任 意の有限時間において有界である.

補題 3 ：式 (15) の動的システムの平衡点 $r=0$ は, $\beta \neq 0$ では不安定である。

証明： 式 (19) の局所的正定関数 $V$ を用いると, 文献 [22] の不安定性定理より，明らかである。

定義 1 (登用領域)：ゼロホロノミー曲線は, $h_{3}\left(\phi_{1}, \phi_{2}\right)$ の符号 の違いにより， $\phi_{1}-\phi_{2}$ 平面を二つの領域に分ける. 登用領域は, $\left(\phi_{1 d}, \phi_{2 d}\right)$ を含み, あらゆる点で $h_{3}\left(\phi_{1}, \phi_{2}\right)$ が $h_{3}\left(\phi_{1 d}, \phi_{2 d}\right)$ と 同じ符号を持つ単連結領域である.

補題 4: 登用領域で, 変数 $\eta_{4}$ は $h_{3}\left(\phi_{1 d}, \phi_{2 d}\right)$ と同符号を 持つ.

証明：定義より $r \geq 0$ でなので, 式 (22)より，登用領域で $\eta_{3}$ は $h_{3}\left(\phi_{1 d}, \phi_{2 d}\right)$ と同じ符号を持つ. 式 (12)の $\eta_{4}$ の定義 より，命題は明らかである.

定理 $1:$ ( $\beta$ と $r$ の零への渐近収束)

(A) 動径不変向角 $\beta$ は零へ渐近収束し, かつ

（B）式（17）の仮定の下に制御入力を式（15）(16）とすると, 極座標 $r$ は零へ漸近収束する.

証明 :

(A) 変数 $\delta$ を点 $\left(\phi_{1 d}, \phi_{2 d}\right)$ とゼロホロノミー曲線との最小 距離とする. 式 (17) の第二の仮定より, $\delta>0$ である. 微小 な正の数 $\epsilon$ と制御器パラメータ $\sigma$ を $\sigma+\epsilon=\delta$ となるように選 ぶ. 注 4 より, $r$ の軌道は有限時間内に $N_{\epsilon}=\{r \in R: r \leq \delta\}$ に入り， $N_{\epsilon}$ のなかに閉じこめられる。補題 2 より，この有限 時間において, 動径不変向角 $\beta$ は有界である. $r$ が $N_{\epsilon}$ に入っ た後に， $\beta$ が漸近的に零に収束することは, 次式のリヤプノフ 関数 $V_{1}$ を用いて得られる.

$$
V_{1}=\frac{1}{2} \beta^{2}
$$

式（13）と式（16）を用いると， $V_{1}$ の微分は

$$
\begin{aligned}
\dot{V}_{1} & =\beta \dot{\beta}=\beta \eta_{4} \dot{\psi} \\
& =-\gamma \eta_{4} \operatorname{sign}\left[h_{3}\left(\phi_{1 d}, \phi_{2 d}\right)\right] \beta \tanh \left[n_{2} \beta\right]
\end{aligned}
$$


となる. $\dot{V}_{1}$ は負定であり, $t \rightarrow \infty$ のときに $\beta \rightarrow 0$ となるこ とが，以下の 4 項から結論できる：(i) $\beta \tanh \left[n_{2} \beta\right]$ は正定, (ii) $\eta_{4}$ は $h_{3}\left(\phi_{1 d}, \phi_{2 d}\right)$ と同符号, (iii) $h_{3}\left(\phi_{1 d}, \phi_{2 d}\right) \neq 0$, (iv) $\beta \neq 0$ なら $\eta_{4} \neq 0$. (i) は明らかであり，(iii）は式（17）の仮 定に基づく. (ii) は補題 4 および $N_{\epsilon}$ が登用領域のなかにある という事実に従う. 補題 3 より $\beta \neq 0$ ならば $r=0$ は不安定 な平衡点であり，式（17）の仮定より $r(0) \neq 0$ である. また， 登用領域内では $h_{3} \neq 0$ である。 それゆえ，登用領域内では $\beta \neq 0$ なら $\eta_{3}=r h_{3} \neq 0$ が存在する. さらに, 登用領域内の 至るところ， $\eta_{3}$ は同じ符号である。いま（iv）は, 式 (12) の $\eta_{4}$ の定義より明らかである.

(B) 時刻 $t=0$ から開始した $r$ の軌道が, $t=T$ に注 4 で定義した $N_{\epsilon}$ に入るとする. $T=t_{0}<t_{1}<t_{2}<\cdots$ の時刻列 $t_{0}, t_{1}, t_{2}, \cdots$ を考える. これらの時刻の $\beta(t)$ の 値をおのおの $P_{0}, P_{1}, P_{2}, \cdots$ と表す．言い換えると， $P_{i}=$ $\beta\left(t_{i}\right), i=0,1,2, \cdots$ である. (A) より, $\forall t \geq T=t_{0}$

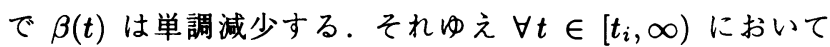
$\beta(t) \leq P_{i}$ であり, $P_{i} \geq P_{i+1}, i=0,1,2, \cdots$ である. 閉 集合 $S_{i}=\left\{r \in R: r \leq \sigma \sqrt{\tanh \left[n_{1} P_{i}^{2}\right]}\right\}$ を定義する. $S_{i} \subset U_{i}=\left\{r \in R: r \leq \epsilon+\sigma \sqrt{\tanh \left[n_{1} P_{i}^{2}\right]}\right\}, i=0,1,2, \cdots$ とすると, $U_{i+1} \subset U_{i}, i=0,1,2, \cdots$ となる．再帰的に時刻 $t_{0}=T$ から始まる時刻列をつくる. 時刻 $t_{i}$ に対して, $\forall t \geq t_{i}$ のとき $\beta(t) \leq P_{i}$ なので, 補題 1 の大域的かつ一様な終局的有 界性により, $t=t_{i}$ から始まる有限期間の後に $r$ の軌道は $U_{i}$ に閉じこめられることになる。この期間を $t_{i}^{\prime}$ と表し

$$
t_{i}^{\prime \prime}=\min \left\{t: \beta(t) \leq P_{i} / 2\right\}-t_{i}, t_{i+1}=t_{i}+\max \left\{t_{i}^{\prime}, t_{i}^{\prime \prime}\right\}
$$

を定義する。この時刻列において， $P_{i+1} \leq P_{i} / 2 \leq P_{0} / 2^{i+1}$ である、いまや $r$ の零への収束を証明できる，与えられた任 意の $\kappa>0$ に対して, $\epsilon+\sigma \sqrt{\tanh \left[n_{1} P_{I}^{2}\right]}<\kappa$ となるよう, $\epsilon=\kappa / 2$ と $i=I$ を選ぶことができる.すると, $r$ の軌道は $\forall t>t_{I}$ で $U_{I}$ に閉じこめられ， $r(t) \in U_{I}$ となる。 それゆえ， $\forall t>t_{I}$ において, $r(t)<\kappa$ であり,このことは $t \rightarrow \infty$ のと きに $r \rightarrow 0$ となることを意味する.

注 5： 定理 1 の（A）の証明に基づくと，式（15）中の制御 器パラメー夕 $\sigma$ は, $\sigma=\delta-\epsilon$ と書かれる. $\delta$ は関節空間の目 標点 $\left(\phi_{1}, \phi_{2}\right)=\left(\phi_{1 d}, \phi_{2 d}\right)$ とゼロホロノミー曲線の最短距離で あり, $\epsilon$ は $\delta$ よりさい微小数である. 例えば, $\epsilon=0.1 \delta$ とす ると, $\sigma$ を $\sigma=0.9 \delta$ のように選ぶ.

注 $6: \delta$ が微小ではないとき, $0<\sigma<\delta$ が必要なだけなの で, $\sigma$ には選択の自由度がある。この状況では, マニピュレー 夕の関節動作範囲の制限を付加的に考慮することができる.

\section{5. 二つの修正制御器}

\section{1 提莱された制御器の限界}

3.4 節の注 2 における制御器の限界に関する注釈を解明する。 目標の関節位置がゼロホロノミー曲線に近いことは， $\delta$ が微小 であることを意味し，相対的に選ばれる $\sigma$ はさらに小さくな る、そのためにマニピュレー夕関節は微小な運動を生じ, 台座 の遅い方向転換と遅い収束という結果になる．続く二つの節で, 二つの修正制御器を提案する。 これらの制御器は，目標関節位

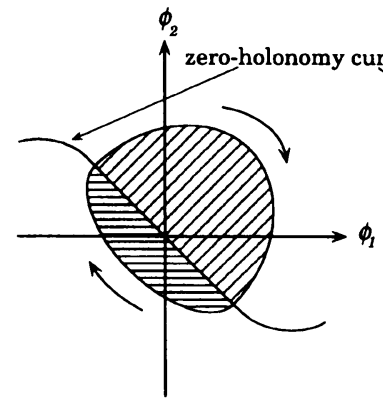

(a)

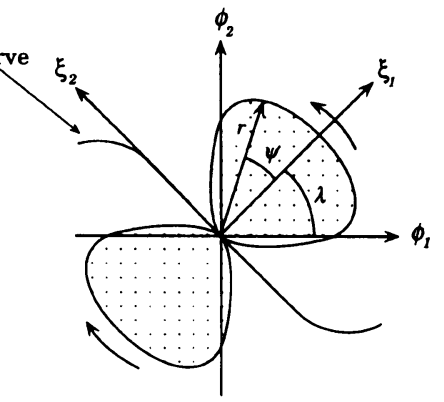

(b)
Fig. 4 Two different strategies for avoiding a zero surface integral; (a) first order Lie bracket motion, (b) second order Lie bracket motion

置がゼロホロノミー曲線に近いときだけ使われるべきで，その 場合に速い収束率が期待できる．第一修正制御器は提案した制 御器と同样に一次 Lie 括弧積運動を用いるが，第二修正制御器 は二次 Lie 括弧積運動を用いる。

\section{2 第一修正制御器}

$\delta$ が微小であると, 3 章の制御器はパラメータ $\sigma$ の制約, す なわち $\sigma<\delta$ に起因した遅い収束率に悩まされる。この選択 は, $\beta$ が結果的に単調滅少するよう，関節経路を有限期間は完 全に登用領域に閉じこめるために用いられた。この限界を克服 する一方法は, $\beta$ への単調減少の要請を外すことである，そう すると $\sigma$ への制約がなくなり，関節がゼロホロノミー曲線の両 側に動けるように, 制御器を修正できる。しかし， $\beta$ の大きさ が大局的に減少することを保証するために，登用領域の関節経 路の面積分がゼロホロノミー曲線の反対側の面積分より大きく なければならない（Fig.4(a))。この目的で, 3.4 節の式 (15) の制御器を次のように修正する。

$$
\begin{aligned}
v_{1} & =\alpha r\left(\sigma^{2} \omega \tanh \left[n_{1} \beta^{2}\right]-r^{2}\right) \\
\omega & \triangleq 1+\tanh \left(n_{3} \operatorname{sign}\left[h_{3}\left(\phi_{1 d}, \phi_{2 d}\right)\right] h_{3}\left(\phi_{1}, \phi_{2}\right)\right)
\end{aligned}
$$

ただし，制御器パラメータ $n_{3}$ は正である。式 (16) の制御器, 式 (17) の仮定, 式 (18) の実際の入力 $u_{1}, u_{2}$ と制御変数 $v_{1}$, $v_{2}$ との関係は前のままである. 式 $(25)$ の $\omega \in(0,2)$ は常に正 で, $\operatorname{sign}\left[h_{3}\left(\phi_{1 d}, \phi_{2 d}\right)\right] h_{3}\left(\phi_{1}, \phi_{2}\right)$ が正のときには大きな値, 同 項が負のときには小さな値となる。これにより，マニピュレー 夕は登用領域で大きな面積をゼロホロノミー曲線の反対側で小 さな面積を周回しようとする.

もはや関節経路が登用領域にとどまる必要はないので, $\sigma<\delta$ という制限は取り除かれた。それれえ，目標姿勢がゼロホロノ ミ一曲線に近い場合には, 上記の制御器は 3.4 節の制御器に比 べて速い収束率が期待できる．また，制約が取り除かれたので， マニピュレータの関節制限を回避するように $\sigma$ を自由に選べ る，その代わり，4 章の議論は，もはや閉ループ系の状態の収 束を保証できない，修正制御器の閉ループ系の安定性解析は, 今後に研究する余地があるが，この論文では行わない.

\section{3 第二修正制御器}

第二修正制御器の発想は, 二次 Lie 括弧積運動に基づくもの であり，面積分の値を大きくするために，ゼロホロノミー曲線 
Table 1 Initial and final configurations of the space robot

\begin{tabular}{|c|c|c|c|c|c|c|c|}
\hline Case & Controller & \multicolumn{3}{|c|}{$\left(\begin{array}{lll}\theta & \phi_{1} & \phi_{2}\end{array}\right)$} & $(\theta$ & $\phi_{1 d}$ & $\left.\phi_{2 d}\right)$ \\
\hline (A) Reorientation maneuver & Section 3.4 & $\left(0^{\circ}\right.$ & $-60^{\circ}$ & $\left.-60^{\circ}\right)$ & $\left(15^{\circ}\right.$ & $\frac{11 a}{-60^{\circ}}$ & $\frac{4 a 1}{\left.-60^{\circ}\right)}$ \\
\hline (B) Reshape maneuver & Section 3.4 & $(30$ & $0^{\circ}$ & $\left.0^{\circ}\right)$ & $\left(30^{\circ}\right.$ & $45^{\circ}$ & $\left.60^{\circ}\right)$ \\
\hline (C) General maneuver & Section 5.2 & $(15$ & $90^{\circ}$ & $\left.90^{\circ}\right)$ & $\left(0^{\circ}\right.$ & $0^{\circ}$ & $\left.0^{\circ}\right)$ \\
\hline (D) Reorientation maneuver & Section 5.3 & $\left(0^{\circ}\right.$ & $0^{\circ}$ & $\left.0^{\circ}\right)$ & $\left(15^{\circ}\right.$ & $0^{\circ}$ & $\left.0^{\circ}\right)$ \\
\hline
\end{tabular}
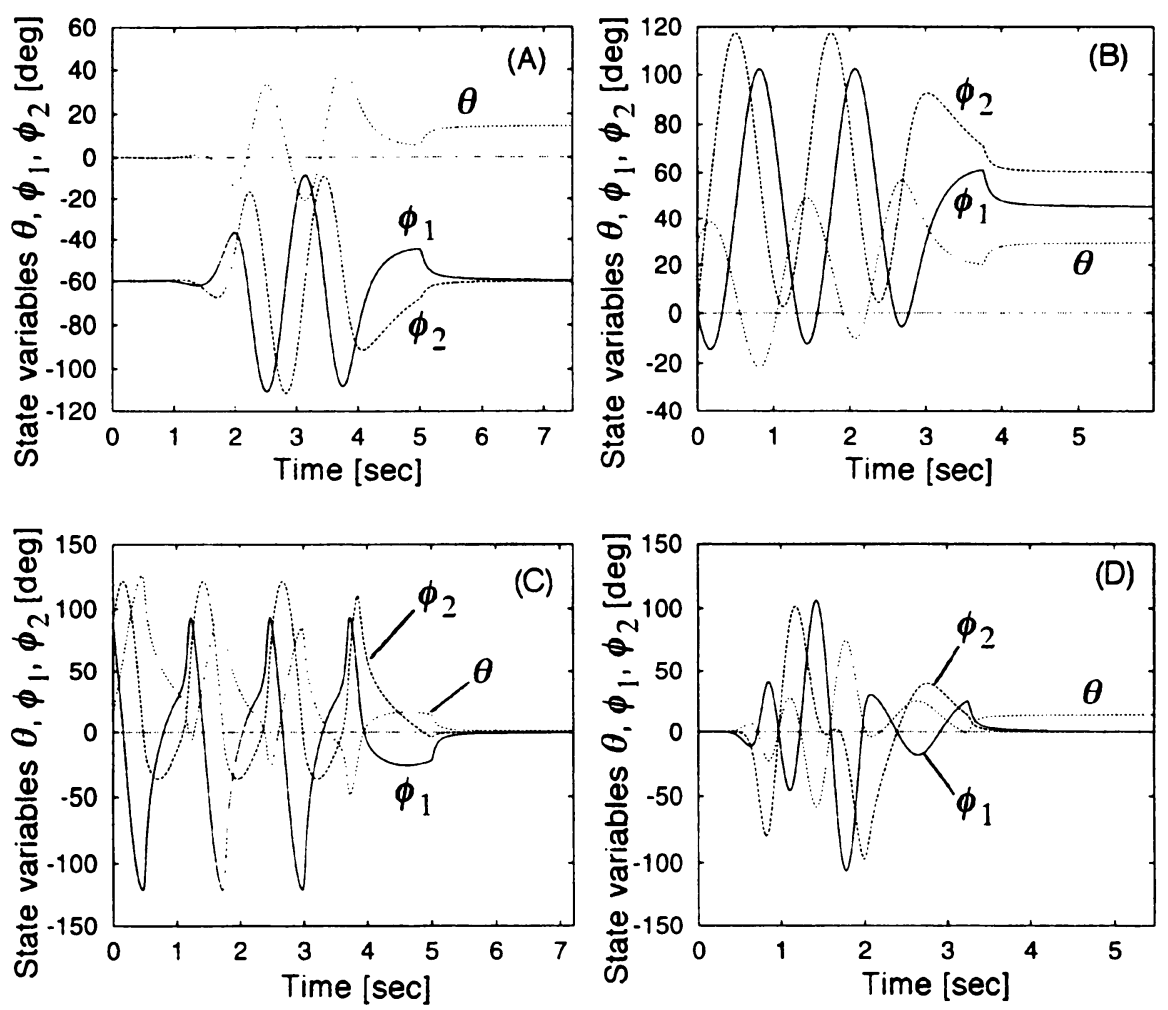

Fig. 5 Time histories of the state variables

を横切る際にFig.4(b) のように回転方向を変える。その目的 で, 誤差変数 $\widehat{\phi}_{1}, \widehat{\phi}_{2}$ を次の座標 $\xi_{1}, \xi_{2}$ に回転一次変換する ことにより，3.4 節の制御器を修正する.

$$
\left(\begin{array}{l}
\xi_{1} \\
\xi_{2}
\end{array}\right)=\left(\begin{array}{rr}
\cos \lambda & \sin \lambda \\
-\sin \lambda & \cos \lambda
\end{array}\right)\left(\begin{array}{l}
\widehat{\phi}_{1} \\
\widehat{\phi}_{2}
\end{array}\right)
$$

Fig. 4(b) に示すように, 二次 Lie 括弧積運動を射影した経路 が, 目標姿勢に最も近い点でゼロホロノミー曲線に直交するよ うに入を選ぶ. 次段階として, 次の関係を用いて $\xi_{1}$ と $\xi_{2}$ を $r, \psi($ 極座標ではない) に変換する.

$$
\begin{aligned}
& \xi_{1}=r \cos \psi \\
& \xi_{2}=r \sin 2 \psi
\end{aligned}
$$

式（15）と式（16）の制御器と式（17）の仮定はそのままであ る. しかし, 実入力 $u_{1}, u_{2}$ と制御変数 $v_{1}, v_{2}$ の関係式 (18) は, 式（26）と式（27）に基づいて以下のように変更する必要 がある。

$$
\left(\begin{array}{l}
u_{1} \\
u_{2}
\end{array}\right)=\left(\begin{array}{cc}
\cos \lambda & -\sin \lambda \\
\sin \lambda & \cos \lambda
\end{array}\right)\left(\begin{array}{cc}
\cos \psi & -r \sin \psi \\
\sin 2 \psi & 2 r \cos 2 \psi
\end{array}\right)\left(\begin{array}{l}
v_{1} \\
v_{2}
\end{array}\right)
$$

これにより, Fig. 4(b) のように, ゼロホロノミー曲線を横切る 都度, 回転方向を変える経路が得られる.また, 第一修正制御 器と同様に, パラメータ $\sigma$ の制約 $\sigma<\delta$ は取り除かれ， $\sigma$ を 関節制限を回避するように選ぶことができる。

\section{6. 数值シミュレーション}

Table 1 の宇宙ロボットの初期と最終の姿勢に対する, 四つ の異なったシミュレーションを示す.ケース (A) と (D) は, 両 端での関節位置を変えることなく台座の向きを変更する．ケー ス $(\mathrm{B})$ は, 両端での台座方向を変えることなく, 関節位置を変 更する姿勢変更であり, ケース (C) は, 関節位置と台座方向の すべてが両端で異なる，一般的な姿勢变更である．目標関節位 置がゼロホロノミー曲線から離れているので, ケース $(\mathrm{A})$ と (B) では, 3.4 節の制御器を用いる。目標関節位置がゼロホロ ノミー曲線に近いので, ケース (C) と (D) では, それぞれ 5.2 節と 5.3 節の制御器を用いる. 全ケースで, Fig. 5 に状態変数 の時刻歴, Fig. 6 に関節变数の経路を示す.

ケース $(\mathbf{A}):$ この場合, $\left(\widehat{\phi}_{1}(0), \widehat{\phi}_{2}(0)\right)=(0,0)$ または $r(0)=0$ であり, 式 (17) の最初の仮定に反する. 初期関節位 置を $\left(\phi_{1}, \phi_{2}\right)=(-60.01,-60.00)$ すなわち $\left(\widehat{\phi}_{1}(0), \widehat{\phi}_{2}(0)\right)=$ 

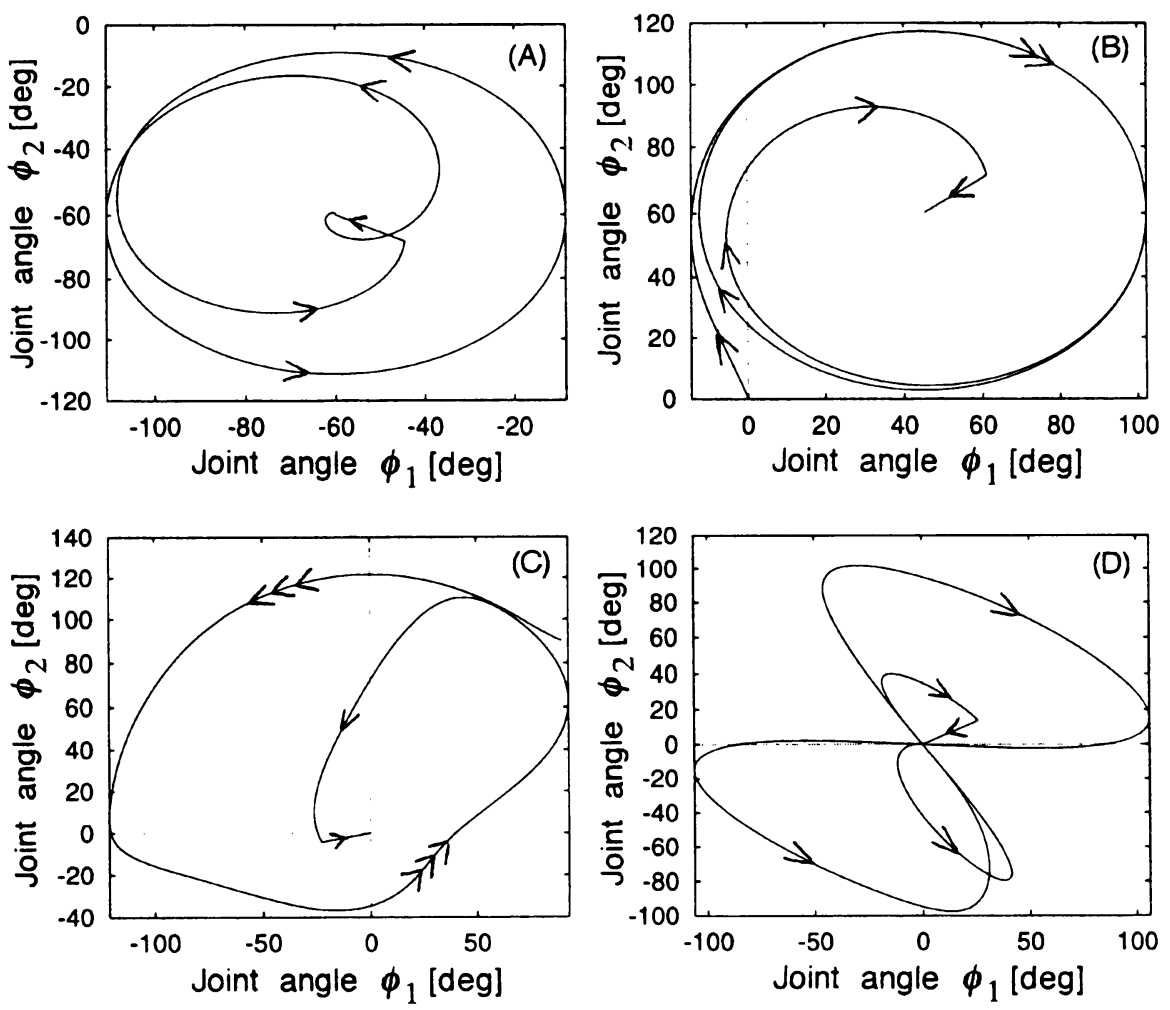

Fig. 6 Trajectories in the shape space of the manipulator

$(0.01,0.00)$ に単に置き換えて,この問題を解決する。このシ ミュレーションには, $\sigma=51.5^{\circ}(0.9$ ラジアン $)$ という值と 3.4 節の制御器を用いる. 初期時刻において $\beta$ が零值でないため に, 点 $r=0$ が不安定であることは, Fig. 6(A) から分かる.

ケース $(\mathrm{B}) ：$ このケースでは, $\sigma=57.3^{\circ}$ (1.0 ラジアン) という值と 3.4 節の制御器を用いる. Fig. 6 (A) と Fig. 6 (B) を 比較すると, ケース (A) では進行方向が反時計回り, ケース (B) では時計回りである。これは，両ケースの目標関節位置が ゼロホロノミー曲線の反対側にあるからである。これらの図か ら，関節経路が目標姿勢に蜾旋形を描いて収束していないこと にも注意されたい。これは， $\beta$ の収束判定基準を約 $0.5^{\circ}$ とし， 一度 $\beta$ がこの值を下回ると, 制御器パラメータ $n_{1}$ と $n_{2}$ を零 にして $r$ を零に収束させるためである，目標位置に向かって関 節が動径方向に動くとき $\beta$ は変化しないので, 終端において両 変数 $r$ と $\beta$ とも, 要求基準の収束を達成できる。これは, 本 質的に制御器が滑らかでないこと意味するが，速い収束のため にはこのような方法が必要である。

ケース (C)：これは, 目標関節位置がゼロホロノミー 曲線上にある場合で，式（17）の第二の仮定に反する. $\operatorname{sign}\left[h_{3}\left(\phi_{1 d}, \phi_{2 d}\right)\right]=-1$ となるように, 目標関節位置を $\left(\phi_{1 d}, \phi_{2 d}\right)=(0.01,0.00)$ とすることにより,この問題を解 決できる. 目標関節位置がゼロホロノミー曲線に非常に近いの で, $\sigma=86^{\circ}$ (1.5 ラジアン) という值と 5.2 節の第一修正制御 器を用いる. Fig. $6(\mathrm{C})$ から, $r$ が零に収束する前に振動して いることが分かる。これは, 制御器が登用領域で大きな面積を 被い, ゼロホロノミー曲線の反対側では小さな面積を被うため
である．図を示していないが，このケースでは関節経路が登用 領域の外に出るため, $\beta$ は単調減少しない.

ケース (D)：このケースの目標関節位置もゼロホロノミー 曲線上にある．前のケースと同様に， $\left(\phi_{1 d}, \phi_{2 d}\right)=(0.01,0.00)$ と仮定することにより，式 (17) の第二の仮定を満足し， $\operatorname{sign}\left[h_{3}\left(\phi_{1 d}, \phi_{2 d}\right)\right]=-1$ となる.ケース $(\mathrm{A})$ と同様に,こ のケースの初期関節位置は, 式 (17) の第二の仮定に反する. $\left(\widehat{\phi}_{1}(0), \widehat{\phi}_{2}(0)\right)=(0.00,0.01)$ または $r(0) \neq 0$ となるように， 初期関節位置を $\left(\phi_{1}, \phi_{2}\right)=(0.01,0.01)$ とすることにより，こ の問題を解決できる．シミュレーションでは， $\sigma=86^{\circ}(1.5 \overline{7}$ ジアン）という值を用いる．Fig. 6 (D) より，ゼロホロノミー 曲線と交わる都度, 関節経路が方向を変えていることが分かる. ゼロホロノミー曲線の傾きを考慮して， $\lambda$ を $60^{\circ}$ に選んだ.

\section{7. 結}

論

本論文では, 浮遊する宇宙平面ロボットの姿勢変更のために, 既存の制御器とは異なる, 滑らかで時不変のフィードバック制 御法を初めて提案した。平衡姿勢を漸近安定化するものではな いが，実質的に任意の姿勢から平衡状態へ系の状態を漸近的に 収束させることができる方法を提案した。この結果は，まず数 学的に示され, 後に数値シミュレーションで確かめられた. 目 標関節位置がゼロホロノミー曲線に極めて近い場合, 制御器は 遅い収束率に恼まされ, 実用的ではない。この問題は, 制御器 の変更によって容易に修正できた。二つの修正法を示したが, 修正制御器を用いた閉ループシステムの安定性は評価しておら ず，今後の課題である。 


\section{参 考 文 献}

[1] Y. Nakamura and R. Mukherjee: "Nonholonomic Path Planning of Space Robots via a Bidirectional Approach," IEEE Trans. on Robotics and Automation, vol.RA-7, no.4, pp.500$514,1991$.

[2] R.W. Brockett: "Asymptotic Stability and Feedback Stabilization," Differential Geometric Control Theory, Brockett, R.W. et al. (eds.) vol. 27 of Progress in Mathematics, pp.181-283, Birkhauser, 1983.

[3] I. Kolmanovsky and N.H. McClamroch: "Developments in Nonholonomic Control Problems," IEEE Control Systems, vol.15, no.6, pp.20-36, 1995.

[4] J.-B. Pomet: "Explicit Design of Time-varying Stabilizing Control Laws for a Class of Controllable Systems without Drift," Systems and Control Letters, vol.18, pp.147-158, 1992.

[5] L. Gurvits, and Z.X. Li: "Smooth Time-periodic Feedback Solutions for Nonholonomic Motion Planning," in Progress in Nonholonomic Motion Planning, Z.X. Li and J. Canny (eds.), pp.53-108, Kluwer Academic Press, 1992.

[6] A.M. Bloch, N.H. McClamroch and M. Reyhanoglu: "Controllability and Stabilizability Properties of a Nonholonomic Control System," Proc. 29th IEEE Conf. on Decision and Control, pp.1312-1314, 1990.

[7] R.M. Murray and S.S. Sastry: "Nonholonomic Motion Planning: Steering Using Sinusoids," IEEE Trans. on Automatic Control, vol.38, no.5, pp.700-713, 1991.

[8] A.M. Bloch, M. Reyhanoglu and N.H. McClamroch: "Control and Stabilization of Nonholonomic Dynamical Systems," IEEE Trans. on Automatic Control, vol.37, no.11, pp.17461757, 1992.

[9] R.W. Longman, R.E. Lindberg and M.F. Zedd: "SatelliteMounted Robot Manipulators-New Kinematics and Reaction Moment Compensation," The International Journal of Robotics Research, vol.6, no.3, 1987, pp.87-103.

[10] Z. Vafa and S. Dubowsky: "On the Dynamics of Space Manipulators Using the Virtual Manipulator, with Applications to Path Planning," The Journal of the Astronautical Sciences, vol.38, no.4, pp.441-472, 1990 .
[11] E.G. Papadopoulos: "Path Planning for Space Manipulators Exhibiting Nonholonomic Behavior," Proc. IEEE/RSJ Conf. on Intelligent Robots and Systems, pp.669-675, 1992.

[12] 山田：“宇宙ロボットのアーム運動による本体の姿勢制御”, 計測自 動制御学会論文集, vol.29, no.4, pp.447-454, 1993.

[13] 秋山, 坂和：“宇宙ロボットの非線形計画による軌道計画”, 計測自 動制御学会論文集, vol.31, no.2, pp.193-197, 1995.

[14] 船木, 羅：“宇宙ロボットシステムの可制御性に関する一考察”, 日 本ロボット学会誌, vol.14, no.7, pp.1077-1084, 1996.

[15] C. Fernandes, L. Gurvits and Z.X. Li: "Attitude Control of Space Platform/Manipulator System Using Internal Motion," Proc. IEEE Conf. on Robotics and Automation, pp.893-898, 1992.

[16] M. Reyhanoglu and N.H. McClamroch: "Reorientation Maneuvers of Planar Multibody Systems in Space Using Internal Controls," AIAA Journal of Guidance, Control and Dynamics, vol.15, no.6, pp.1475-1480, 1992.

[17] N. Sreenath: "Nonlinear Control of Planar Multibody Systems in Shape Space," Math. Control Systems, vol.5, pp.343-363, 1992.

[18] R. Mukherjee and M. Zurowski: "Reorientation of a Atructure in Apace Using a Three Link Rigid Manipulator," AIAA Journal of Guidance, Control, and Dynamics, vol.17, no.4, pp.840$847,1994$.

[19] G.C. Walsh and S.S. Sastry: "On Reorienting Linked Rigid Bodies Using Internal Motion," IEEE Trans. on Robotics and Automation, vol.11, no.1, pp.139-145, 1995.

[20] I. Kolmanovsky and N.H. McClamroch: "Feedback Reorientation of Planar Multibody Systems in Space Using Joint Actuation," Proc. American Control Conference, pp.2810-2814, 1995.

[21] 山田：“宇宙ロボットのアーム運動による本体姿勢のフィードバック制 御”，システム制御情報学会論文誌, vol.9, no.6, pp.296-304, 1996.

[22] M. Vidyasagar: "Nonlinear Systems Analysis," Prentice Hall, Englewood Cliffs, NJ, 1993.

[23] R. Mukherjee: "Pseudo-holonomic Behavior of Planar Space Robots," AIAA Journal of Guidance, Control, and Dynamics, vol.19, no.1, pp.251-253, 1996.

[24] J. La Salle and S. Lefschetz: Stability by Liapunov's Direct Method, Academic Press, 1961.

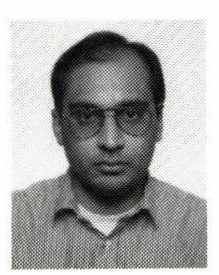

ランジャン・ムカジー（Ranjan Mukherjee）

1965 年 8 月 19 日生. 1991 年カリフォルニア大学 サンタバーバラ校博士課程修了。同年 9 月海軍大 学院大学助教授, 1996 年ミシガン州立大学準教 授. 1993 年最優秀発表論文賞 (AIAA GNC) な ど受賞. 非ホロノミック制御，医療ロボットなと の研究に従事. Ph.D. ASME, IEEE, ASEEの会

員.

(日本ロボット学会正会員)

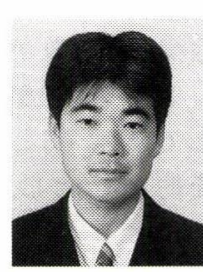

掃部雅幸 (Masayuki Kamon)

1971 年 1 月 2 日生. 1996 年慶應大学大学院修士課 程 (機械工学専攻) 修了, 1996-1997 年ミシガン州 立大学客員研究員. その間, 宇宙ロボットの非ホロ ノミック制御の研究に従事. 1997 年 4 月より川崎重 工業株式会社に勤務。（日本ロボット学会正会員）

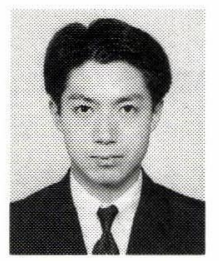

泉田 啓 (Kei Senda)

1963 年 8 月 17 日生. 1988 年大阪府立大学大学院 修士課程 (航空工学専攻) 修了. 同年 4 月大阪府立 大学工学部助手, 1994 年同助教授, 1996-1997 年 ミシガン州立大学客員研究員. 1992 年最優秀発表 論文賞 (AIAA GNC), 1994 年システム制御情報 学会賞など受賞. 宇宙ロボット, 柔軟マニピュレー 夕などの研究に従事. 博士 (工学). AIAA などの会員.

(日本ロボット学会正会員) 